\title{
Enhanced Multi-Faceted Teaching Methods: Phase II
}

Dennis L. Payette, (Email: payette@adelphi.edu), Adelphi University Daniel Verreault, (Email: dverreault@ut.edu), University of Tampa

\begin{abstract}
This paper is an extension of a previously published paper of the same name which created a matrix of soft and hard learning technologies and two evaluation scales measuring the value of use and level of use of various teaching technologies and methods for undergraduate and graduate students. A questionnaire was subsequently developed to gather data from full time faculty on the actual classroom utilization and evaluation of sixteen "hard" and "soft" teaching technologies. This paper represents the analysis of data from eighteen faculty members from the Adelphi University School of Business. The third phase of this research will gather data from adjunct faculty to develop comparisons between the two groups.
\end{abstract}

\section{INTRODUCTION}

n 2003, this research began with the intent of developing an instrument to measure "level of use" and "value of use" of various teaching technologies and methodologies of the full time business faculty at the

Adelphi University School of Business. An instrument was designed and presented at the Teaching and Learning Conference in January 2004. The paper was subsequently accepted for publication (Payette 2004). With the encouragement of that experience and valuable input from the paper presentation and comments from colleagues it was decided to pretest the instrument and then administer it to the full time business faculty at Adelphi University. This was done during the Spring semester and Summer of 2004. Data analysis began in the Fall semester of 2004 and completed in mid November 2004. This paper describes the results of that data analysis.

The overarching goal of the research was to have an accurate portrait of what methods and technologies faculty actually use and then evaluate the methods from a variety of perspectives, i.e., hard technologies, soft technologies, and classroom types. The data will be used for discussion with faculty on continuous improvement initiatives in providing high quality instruction throughout The School of Business.

\section{PREVIOUS RESEARCH}

We know from the classic study on diffusion of technology by Rogers (1983, p.5) that innovations do not take place evenly over time nor are they universally accepted. Rogers suggested many complex and interdependent characteristics must be present for adoption to occur. In recent years a barrage of new teaching and learning technologies have developed including course management software (Morgan 2003), laptop computers for students and faculty (Hall 2003, p.301) as well as the belief that new teaching methods such as collaborative learning (Gokhale 2003) can make a positive difference in student learning. Morgan (2003, p.2) reported on a statewide study of the University of Wisconsin that "the use of course management systems by faculty in the University of Wisconsin system are increasing rapidly, but much of this use is concentrated on the content presentation tool within the CMS."

Other studies focus on the use of the internet technologies to enhance instruction (MA 2004, p.5,6) that, "In comparison with the traditional teaching model, the new teaching model clearly offers a superior instructional approach... and the internet is seen as a vehicle to increase academic productivity and enhance academic effectiveness in institutions of higher learning". 
Others are not quite as certain about the role of technology and see new methods and technology as a support mechanism "but it does not take the place of fundamental teaching tasks" (Wark 2004, p.2). In a paper on the use of the Wide World Web on teaching Alexander (1995, p.1) suggested that "many adopters of new technologies such as Wide World Web have as their primary focus, the features of the new technology." Her research goes on to say that focus on technological features instead of learning as the goal results in surprise when "learning gains are not realized." Another factor inhibiting the growth and perhaps the effectiveness of learning with new technologies is the major training and support requirements needed for an "e-learning environment (Arabasz and Baker 2003, p.5, 6). Some research now shows dramatic growth in the development of support centers throughout the world (see Dalhousie University listing of support centers on http://dal.ca/noidt/ids/html). For information on new technological means of enhancing instruction see "The Collaboration for the Advancement of College Teaching and Learning at http://collab.org.

The Educause Center for Applied Research (ECAR) recently completed a major survey of student use of information technology (Caruso 2004, p.1). Interestingly, this study focused on "level of skill" and "benefits of the use of technology in the classroom" which closely parallels the scales used in the study on faculty use in the present study. The ECAR study supports the premise that more information is needed about both students and faculty on level of use, level of skill, and value of use to more fully understand the perceived effects of technology upon learning. The Chronicle of Higher Education, in an article by Young, on the ECAR study reported that "Colleges have spent a lot of money putting technology in the classroom, and while innovations have made courses more convenient, the spending has yet to have a large impact on learning..." (Chronicle of Higher Education; 8/13/04, p. A28).

Since the instant study is focused on business faculty at Adelphi University a brief review of their efforts to enhance learning technologies for students and faculty alike is appropriate. Adelphi, like many institutions, continues to make major investments in infrastructure, technology, training, and support. In 2001, Bradley and Quigley developed a presentation, "Transforming the Faculty: A Case Study at a Comprehensive University (2001). In addition to a student help center centrally located in the library a dedicated faculty facility, the Faculty Center for Professional Excellence, was created and staffed to provide in service training and support for all faculty (http://fcpe.adelphi.edu). Technical and training support is also provided by the Information Technology Center (http://infotech.adelphi.edu) in addition to the FCPE.

The preceding review has barely covered the body of literature that now exists on the subject of technology and learning in higher education. What it has done, however, is to demonstrate that changes in teaching and technologies is in fact happening on a widespread basis as witnessed by global resources and research. This review was intended to lay the groundwork for the faculty research at the School of Business at Adelphi University. Finally, as Ma and Runyon (2004, p.1) reported "There is little doubt that technology has the potential to enhance teaching and learning, but there is a lack of agreement on how it should be used for improving academic productivity and enhancing higher learning".

\section{SAMPLE DESCRIPTION}

We administered the questionnaire to twenty-four faculty members and received eighteen responses for a seventy-five percent response rate. We collected data on three factors "Teaching Experience" at four levels; "Teaching Field" for the five departments; and "Tenure" status. Technologies/Methods investigated were classified under three categories; "Soft" technologies, "Hard" technologies, and "Class Room" type. "Soft" technologies consisted of Essay Exams, Attendance, Research Projects, Guest Lecturers, and Student Teams. Hard Technologies consisted of Overhead Projectors, Email, Streaming Video, Internet Access, BlackBoard, PowerPoint, Publisher Aids, Laser Pointer, Laptop computers, Elmo Projector, and Infocus Projector. Classrooms were divided into Smart Classrooms, Hybrid Classrooms, and Standard Classrooms.

Responses were numerical at five levels on both the level of use and the value of use of each Technology/Method at both the graduate and undergraduate levels. The responses numbered " 5 " for both the Level of Use scale (response 5 is "Intend to use") and Value of Use scale (response five is "Have not used") did not enter into 
the primary analysis. The response "Intend to use" was collected as a measure of demand or sentiment for a technology or method. For primary statistical analysis, "Intend to use" responses were recoded into the response "Never" which is the first scale item for analysis. The response "Have not used" was collected as a response for those not able to make an assessment of the value of a particular technology or method and was coded as missing for analysis. Analyzed responses were at four levels. See Figure 1 for the data collection instrument. Figure 2 shows the instrument complete with demographic data and mean responses to the questions.

Figure 1 - Survey Instrument

Faculty Survey on Teaching Methods and Technologies

\begin{tabular}{|c|c|c|c|c|c|}
\hline Teaching Experience: & $<3$ & $4-7$ years & $8-12$ years & $>12$ & \\
\hline Teaching Field: & Acct___ & Fin & Mkt__ & Mgmt & MIS/OPS \\
\hline Tenured? & Yes ___ & No & & & \\
\hline
\end{tabular}

Scales:

Level of Use

1. Never

2. Occasionally

3. Frequently

4. Always

5. Intend to use
Value of Use

1. Worthless

2. Worthwhile

3. Good

4. Very good

5. Have not used

Teaching Methods and Technologies with Level of Use and Value of Use

\begin{tabular}{|c|c|c|c|c|}
\hline \multirow[b]{2}{*}{ Technologies/Methods } & \multicolumn{2}{|c|}{ Graduate } & \multicolumn{2}{|c|}{ Undergraduate } \\
\hline & Level of Use & Value of Use & Level of Use & Value of Use \\
\hline \multicolumn{5}{|l|}{ Soft Technologies } \\
\hline \multicolumn{5}{|l|}{ Essay Examinations } \\
\hline \multicolumn{5}{|l|}{ Attendance } \\
\hline \multicolumn{5}{|l|}{ Research Projects } \\
\hline \multicolumn{5}{|l|}{ Guest Lecturers } \\
\hline \multicolumn{5}{|l|}{ Student Teams } \\
\hline \multicolumn{5}{|l|}{ Other (specify) } \\
\hline \multicolumn{5}{|l|}{ Hard Technologies } \\
\hline \multicolumn{5}{|l|}{ Overhead Projector } \\
\hline \multicolumn{5}{|l|}{ Email } \\
\hline \multicolumn{5}{|l|}{ Streaming Video } \\
\hline \multicolumn{5}{|l|}{ Internet Access } \\
\hline \multicolumn{5}{|l|}{ Blackboard Program } \\
\hline \multicolumn{5}{|l|}{ PowerPoint } \\
\hline \multicolumn{5}{|l|}{ Publisher Aids, e.g. CD's, VCR, DVD's } \\
\hline \multicolumn{5}{|l|}{ Laser Pointer } \\
\hline \multicolumn{5}{|l|}{ Laptop } \\
\hline \multicolumn{5}{|l|}{ Elmo Projector } \\
\hline \multicolumn{5}{|l|}{ Infocus Projector } \\
\hline \multicolumn{5}{|l|}{ Other (Specify) } \\
\hline \multicolumn{5}{|l|}{ Class Rooms } \\
\hline \multicolumn{5}{|l|}{ Smart Classroom } \\
\hline \multicolumn{5}{|l|}{ Hybrid Classroom } \\
\hline Standard Classroom & & & & \\
\hline
\end{tabular}




\section{RESEARCH QUESTIONS}

The research questions addressed in this paper are:

1. Which technologies or classroom types are valued most highly by faculty?

2. Which technologies or classroom types are used most intensely by faculty?

3. Does the level of teaching, graduate vs. undergraduate, affect the level or value of use of the technologies or classroom types?

4. Are the levels of use and value of use similar for the technologies and classroom types?

5. What are the effects of the factors teaching experience, teaching field, and tenure status on the mean responses for each significant difference?

\section{RESULTS}

\section{Descriptive Statistics}

Table 1 uses the questionnaire format to summarize the sample and to present the mean responses for each of the cells. Two thirds of the sample possessed over twelve years of teaching experience and the sample was evenly split between tenured and non-tenured members. The data collected allows analysis pertinent to research questions one through five by comparing means and then testing for significant differences in means by level of use and value of use within graduate and undergraduate level. The influence of factors was tested through ANOVA on items found significant through testing for mean differences.

Table 1 - Demographics and Mean Responses

Panel A: Respondents

\begin{tabular}{lllll} 
Teaching Experience: & $<3(1)$ & $4-7$ years (4) & $8-12$ years (1) & $>12(12)$ \\
Teaching Field: & Acct (3) & Fin (4) & Mkt (1) & Mgmt (7) \\
\hline Tenure Status: & Yes (9) & No (9) & & MIS/OPS (3)
\end{tabular}

Panel B: Mean Responses - Soft Technologies

\begin{tabular}{|c|c|c|c|c|}
\hline \multirow[b]{2}{*}{ Technologies/Methods } & \multicolumn{2}{|c|}{ Graduate } & \multicolumn{2}{|c|}{ Undergraduate } \\
\hline & Level of Use & Value of Use & Level of Use & Value of Use \\
\hline \multicolumn{5}{|l|}{ "Soft" Technologies } \\
\hline Essay Examinations & 2.72 & 3.44 & 2.44 & 3.00 \\
\hline Attendance & 2.76 & 2.66 & 3.33 & 3.29 \\
\hline Research Projects & 3.22 & 3.69 & 2.63 & 3.21 \\
\hline Guest Lecturers & 1.61 & 3.14 & 1.56 & 3.17 \\
\hline Student Teams & 3.17 & 3.60 & 2.81 & 3.13 \\
\hline
\end{tabular}


Table 1 - Continued

Demographics and Mean Responses

Panel C: Mean Responses - Hard Technologies

\begin{tabular}{|c|c|c|c|c|}
\hline \multirow[b]{2}{*}{ Technologies/Methods } & \multicolumn{2}{|c|}{ Graduate } & \multicolumn{2}{|c|}{ Undergraduate } \\
\hline & Level of Use & Value of Use & Level of Use & Value of Use \\
\hline \multicolumn{5}{|l|}{ "Hard Technologies } \\
\hline Overhead Projector & 1.94 & 2.87 & 2.00 & 2.79 \\
\hline Email & 3.28 & 3.81 & 3.06 & 3.71 \\
\hline Streaming Video & 2.00 & 3.40 & 1.75 & 3.63 \\
\hline Internet Access & 2.61 & 3.64 & 2.31 & 3.64 \\
\hline Blackboard Program & 2.44 & 3.25 & 2.31 & 3.44 \\
\hline PowerPoint & 2.89 & 3.50 & 2.88 & 3.54 \\
\hline Publisher Aids, e.g. CD's, VCR, DVD's & 2.78 & 3.38 & 2.75 & 3.50 \\
\hline Laser Pointer & 1.39 & 2.40 & 1.44 & 2.40 \\
\hline Laptop & 1.83 & 3.44 & 1.71 & 3.50 \\
\hline Elmo Projector & 1.69 & 3.22 & 1.69 & 3.43 \\
\hline Infocus Projector & 2.28 & 3.55 & 2.44 & 3.44 \\
\hline
\end{tabular}

Panel D: Mean Responses - Classroom Types

\begin{tabular}{|l||c|c||c|c||}
\hline \multirow{2}{*}{ Technologies/Methods } & \multicolumn{2}{c||}{ Graduate } & \multicolumn{2}{c||}{ Undergraduate } \\
\cline { 2 - 5 } & Level of Use & \multicolumn{1}{l||}{ Value of Use } & Level of Use & Value of Use \\
\hline \hline Class Rooms & 3.11 & 3.65 & 2.94 & 3.71 \\
\hline \hline Smart Classroom & 1.72 & 3.44 & 1.75 & 3.63 \\
\hline Hybrid Classroom & 2.67 & 2.50 & 2.69 & 2.50 \\
\hline Standard Classroom & \multicolumn{3}{|l|}{} \\
\hline
\end{tabular}

Research Questions 1 and 2: Which technologies and classroom types are valued most highly and used most intensely by faculty?

Questions 1 and 2 address the overall issues of value and level of use for the three categories soft technologies, hard technologies, and classroom types. In order to examine for these items, refer to Figures 2, 3, and 4 that plot the mean values of the responses.

The three highest valued soft technologies (Figure 2) were graduate research projects (3.7), graduate team work (3.6), and graduate essay work (3.4). The three highest valued undergraduate soft technologies were attendance (3.3), research projects (3.2), and guest lecturers (3.1). Essay work (3.0) was ranked somewhat lower in value for the undergraduates (3.0) than for graduate students. We note the relatively high value score for guest lecturers at both the graduate (3.1) and the undergraduate levels (3.2), and the large gap between the value of this techniques and its level of use (1.6) at both the graduate and undergraduate levels.

When reviewing the perceived value of hard technologies, there appears to be strong agreement on the value of certain technologies at both the graduate and undergraduate levels (Figure 3). The means for these values appeared similar and high. All hard technologies except for Overhead Projectors and Laser Pointers had mean scores over three. There was strong perceived value in a host of technologies including e-mail, internet access, streaming video, laptops, BlackBoard, Infocus projectors, Elmo projectors, and Publishers Aids. A visual inspection of the means indicates several areas where the perceived value of use significantly exceeds the level of use of these technologies. 


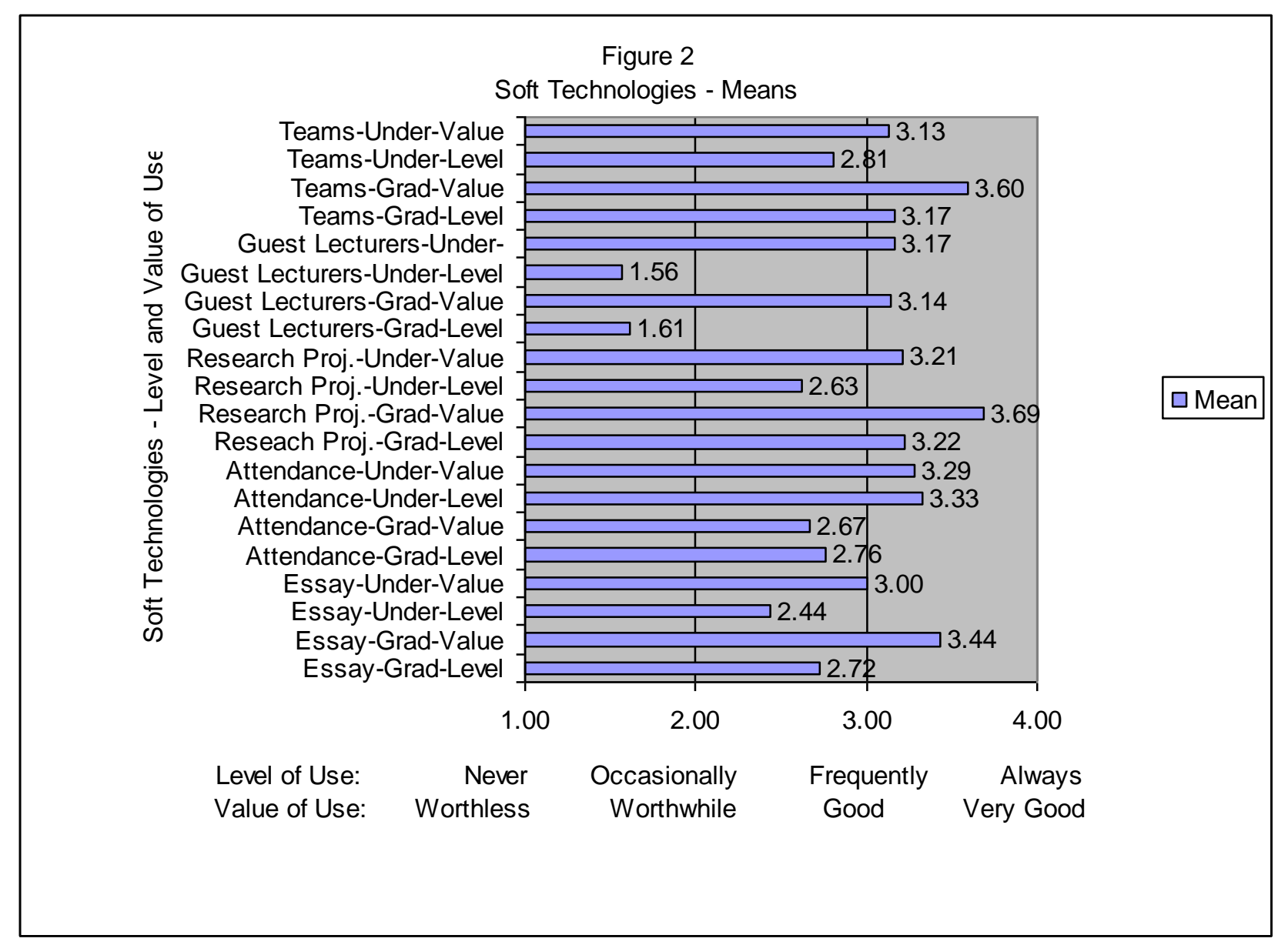

In terms of classroom types (Figure 4), respondents ranked Smart classrooms (3.7) and Hybrid classrooms (3.5) as highly valued and equally valuable at both the undergraduate and graduate levels. Standard classrooms (2.5) received a significantly lower ranking. Similar to the cases of several soft and hard technologies, the level of use of the desired classrooms is lower than their perceived value.

The general pattern of the data set indicates that the values of the technologies or classrooms tend to be higher than their level of use. Only the means for attendance at both the graduate and undergraduate levels appear to describe a case where value and use are in balance. Also, there appear to be some differences in value and level of use when comparing graduate and undergraduate levels. (Note: graduate level courses include MBA and MS Finance classes.)

Research Question 3: Does the level of teaching affect the level or value of use of soft technologies, hard technologies, or classroom types?

In order to examine question three, we ran a series of paired samples t-tests for each technology type (soft and hard) and for classroom types. The pairs were defined as Graduate and Undergraduate for both level and value of use for each individual technology. We used paired sample t-tests because each respondent was measured twice for each pair. (All statistics were run on SPSS v. 12. The column titled "mean" on this and following tables shows the difference in means between the means of the items in the paired samples. These may not match the item means as not all items resulted in pairs due to missing data. The sign denotes which mean was higher.) Table 2 indicates four pairs were significantly different at .05 for either the value or level of use of soft technologies. The value of essays at 
the graduate level was significantly higher (.047) than at the undergraduate level. The level of use of attendance scored significantly higher at the undergraduate level (.012). Consistent with the level of use difference, the value of attendance ranked significantly higher at the undergraduate level (.027). The fourth significant item in soft technologies is that the use of research projects is used at a significantly higher level for graduate students. Interestingly, the value of research projects was not judged as significantly different (.096) at the undergraduate vs. graduate level.

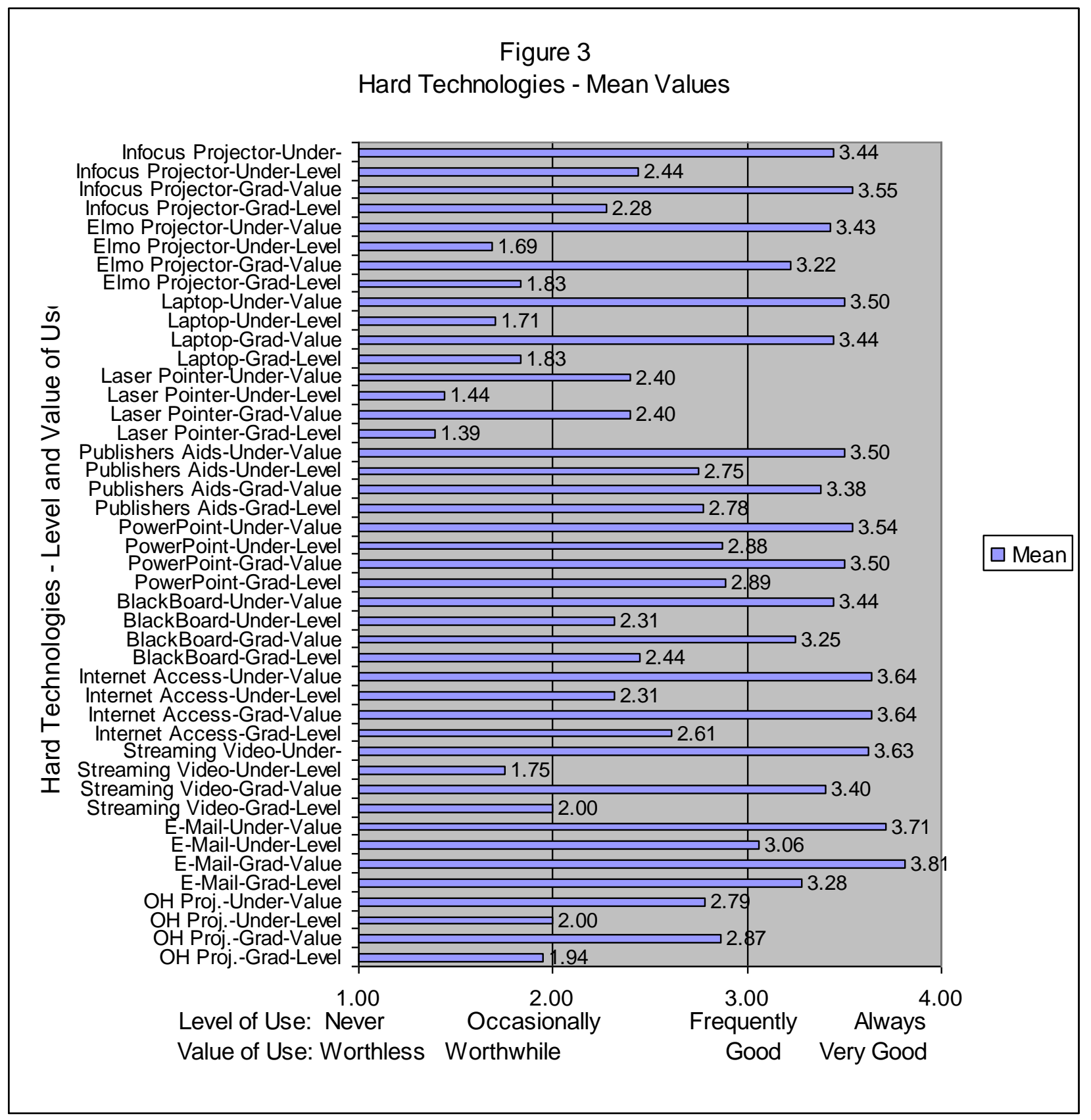




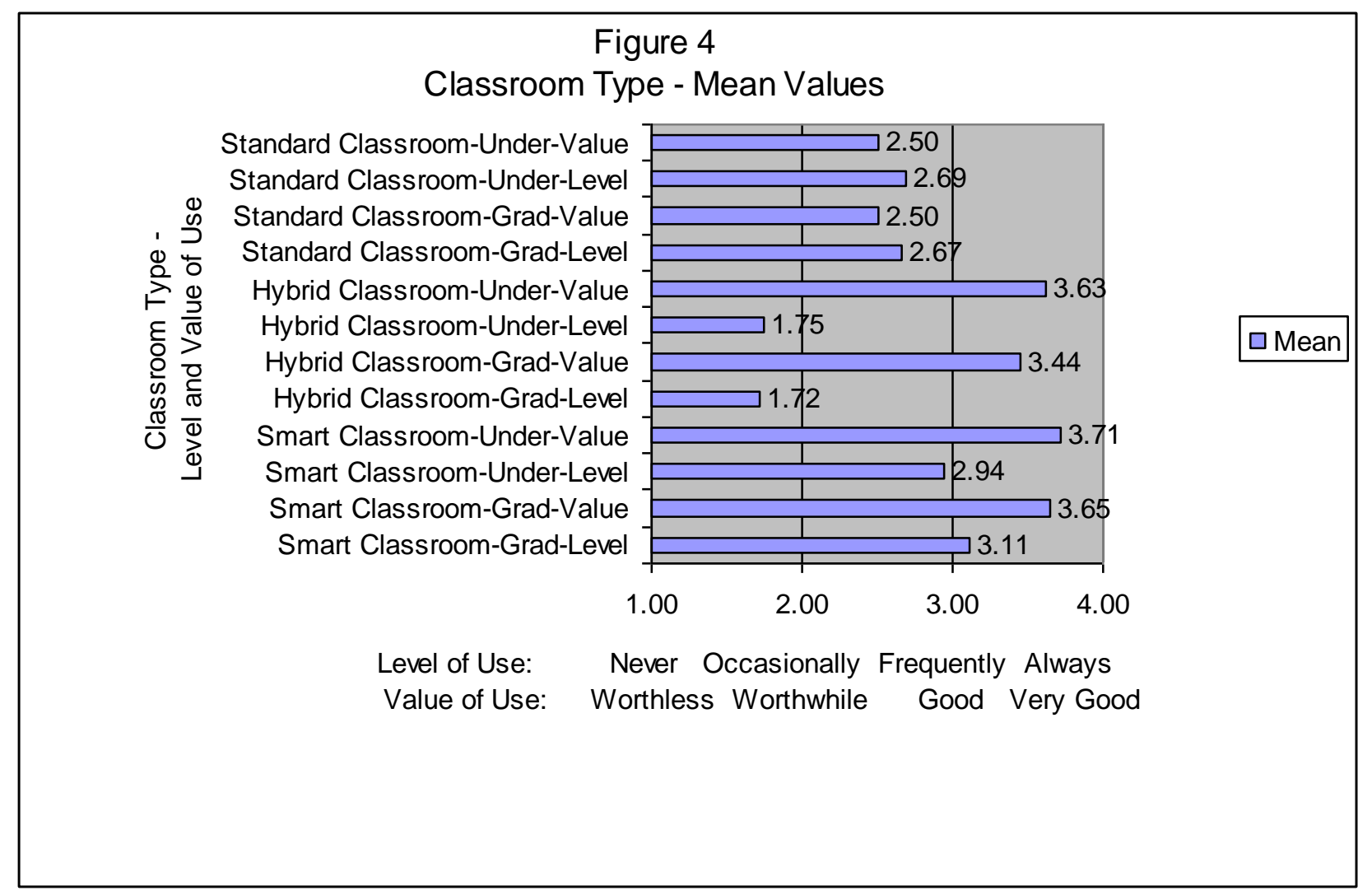

Table 3 presents the results of paired sample t-tests for all pairs of hard technologies and classroom types at both the graduate and undergraduate levels. No significant differences are evident in any of the pairs. Graduate and undergraduate levels are insignificant in explaining the level of use and value of use of the hard technologies and classroom types. This finding is not unexpected, as both undergraduate and graduate classes would experience similar benefits or lack of benefits from technology and class type.

Research Question 4: Are the levels of use and value of use similar for soft technologies, hard technologies and classroom types?

Research question four explores differences between the level of use and the value of use of soft technologies, hard technologies, and classroom types at both the graduate and undergraduate levels. We interpret a significant negative difference between level and value of use as a constraint. These constraints might be self constraints (not taking advantage of training opportunities or not redesigning an existing delivery method), time constraints (perception of inadequate time to utilize or properly implement the technology) or resource constraints (a lack of training opportunities or a physical resource inadequacy). It is beyond the scope of the paper to investigate the nature of the constraints and ways to elevate those constraints. 
Table 2 - Paired Samples T-Test - Soft Technologies By: Graduate vs. Undergraduate - Level and Value of Use

\begin{tabular}{|c|c|c|c|c|c|c|c|c|c|}
\hline & & \multicolumn{5}{|c|}{ Paired Differences } & \multirow[t]{3}{*}{$\mathbf{t}$} & \multirow[t]{3}{*}{ df } & \multirow[t]{3}{*}{$\begin{array}{c}\text { Sig. } \\
\text { (2-tailed) }\end{array}$} \\
\hline & & \multirow[t]{2}{*}{ Mean } & \multirow[t]{2}{*}{$\begin{array}{c}\text { Std. } \\
\text { Deviation }\end{array}$} & \multirow[t]{2}{*}{$\begin{array}{l}\text { Std. } \\
\text { Error } \\
\text { Mean }\end{array}$} & \multicolumn{2}{|c|}{$\begin{array}{l}\text { 95\% Confidence } \\
\text { Interval of the } \\
\text { Difference }\end{array}$} & & & \\
\hline & & & & & Lower & Upper & & & \\
\hline $\begin{array}{l}\text { Pair } \\
1\end{array}$ & $\begin{array}{l}\text { Essay-Grad-Level } \\
\text { Essay-Under-Level }\end{array}$ & .25000 & .85635 & .21409 & -.20632 & .70632 & 1.168 & 15 & .261 \\
\hline $\begin{array}{l}\text { Pair } \\
2\end{array}$ & $\begin{array}{l}\text { Essay-Grad-Value } \\
\text { Essay-Under-Value }\end{array}$ & .50000 & .85485 & .22847 & .00642 & .99358 & 2.188 & 13 & .047 \\
\hline $\begin{array}{l}\text { Pair } \\
3\end{array}$ & $\begin{array}{l}\text { Attendance-Grad-Level Attendance- } \\
\text { Under-Level }\end{array}$ & -.66667 & .89974 & .23231 & -1.16492 & -.16841 & -2.870 & 14 & .012 \\
\hline $\begin{array}{l}\text { Pair } \\
4\end{array}$ & $\begin{array}{l}\text { Attendance-Grad-Value Attendance- } \\
\text { Under-Value }\end{array}$ & -.46154 & .66023 & .18311 & -.86051 & -.06257 & -2.521 & 12 & .027 \\
\hline $\begin{array}{l}\text { Pair } \\
5\end{array}$ & $\begin{array}{l}\text { Research Proj-Grad-Level Research } \\
\text { Proj--Under-Level }\end{array}$ & .50000 & .81650 & .20412 & .06492 & .93508 & 2.449 & 15 & .027 \\
\hline $\begin{array}{l}\text { Pair } \\
6\end{array}$ & $\begin{array}{l}\text { Research Proj.-Grad-Value Research } \\
\text { Proj--Under-Value }\end{array}$ & .38462 & .76795 & .21299 & -.07945 & .84868 & 1.806 & 12 & .096 \\
\hline $\begin{array}{l}\text { Pair } \\
7\end{array}$ & $\begin{array}{l}\text { Guest Lecturers-Grad-Level Guest } \\
\text { Lecturers-Under-Level }\end{array}$ & .00000 & .51640 & .12910 & -.27517 & .27517 & .000 & 15 & 1.000 \\
\hline $\begin{array}{l}\text { Pair } \\
8\end{array}$ & $\begin{array}{l}\text { Guest Lecturers-Grad-Value Guest } \\
\text { Lecturers-Under-Value }\end{array}$ & .09091 & .83121 & .25062 & -.46750 & 64932 & .363 & 10 & .724 \\
\hline $\begin{array}{l}\text { Pair } \\
9\end{array}$ & $\begin{array}{l}\text { Teams-Grad-Level } \\
\text { Teams-Under-Level }\end{array}$ & .31250 & 1.01448 & .25362 & -.22808 & .85308 & 1.232 & 15 & .237 \\
\hline $\begin{array}{l}\text { Pair } \\
10\end{array}$ & $\begin{array}{l}\text { Teams-Grad-Value } \\
\text { Teams-Under-Value }\end{array}$ & .23077 & .43853 & .12163 & -.03423 & .49577 & 1.897 & 12 & .082 \\
\hline
\end{tabular}

Figures in Bold = significant at .05

In terms of soft technologies (see Table 4), the value of essays at the graduate level is significantly higher than that at the undergraduate level (.027). The value of guest lecturers is significantly higher than the level of use of this technique at both the graduate (.000) and undergraduate levels (.000). There is a very strong perception of the usefulness of guest lecturers and a low actual usage. For the remaining variables, we interpret the non-significant findings as indicative that the perceived value and level of use of the technology is in balance.

For hard technologies (See Table 5), nine pairs out of twenty-two show significant differences with all significant pairs indicating that the value of a technology is significantly greater than its use. The value of overhead projectors at both the graduate (.022) and undergraduate levels (.033) significantly exceeds the level of use. Streaming video at both the graduate (.008) and undergraduate levels (.015) are both valued more highly than used. Internet access at the graduate (.026) and undergraduate (.024) likewise are valued more highly than used. Publishers' aids at the undergraduate level (.029), Laptops at the undergraduate level (.018) and Elmo projectors at the undergraduate level (.045) all are valued more highly than used. Most of these differences are perceived to be the product of rationing. As newly designed rooms come increasingly on line, we expect the level and value of use to move to equilibrium. Even the significant difference with respect to overhead projectors fits the rationing scenario as rooms without screens remain without screens as they are slated for remodeling.

Finally, in terms of classroom types (Table 6), hybrid classrooms at both the graduate (.04) and undergraduate (.038) levels are valued more highly than they are used. Standard classrooms, quite consistently, are used at both the graduate (.029) and the undergraduate levels (.028) at a level that is higher than their perceived use. 
Table 3

Paired Samples T-Test - Hard technologies and Classroom Type By: Graduate vs. Undergraduate - Level and Value of Use

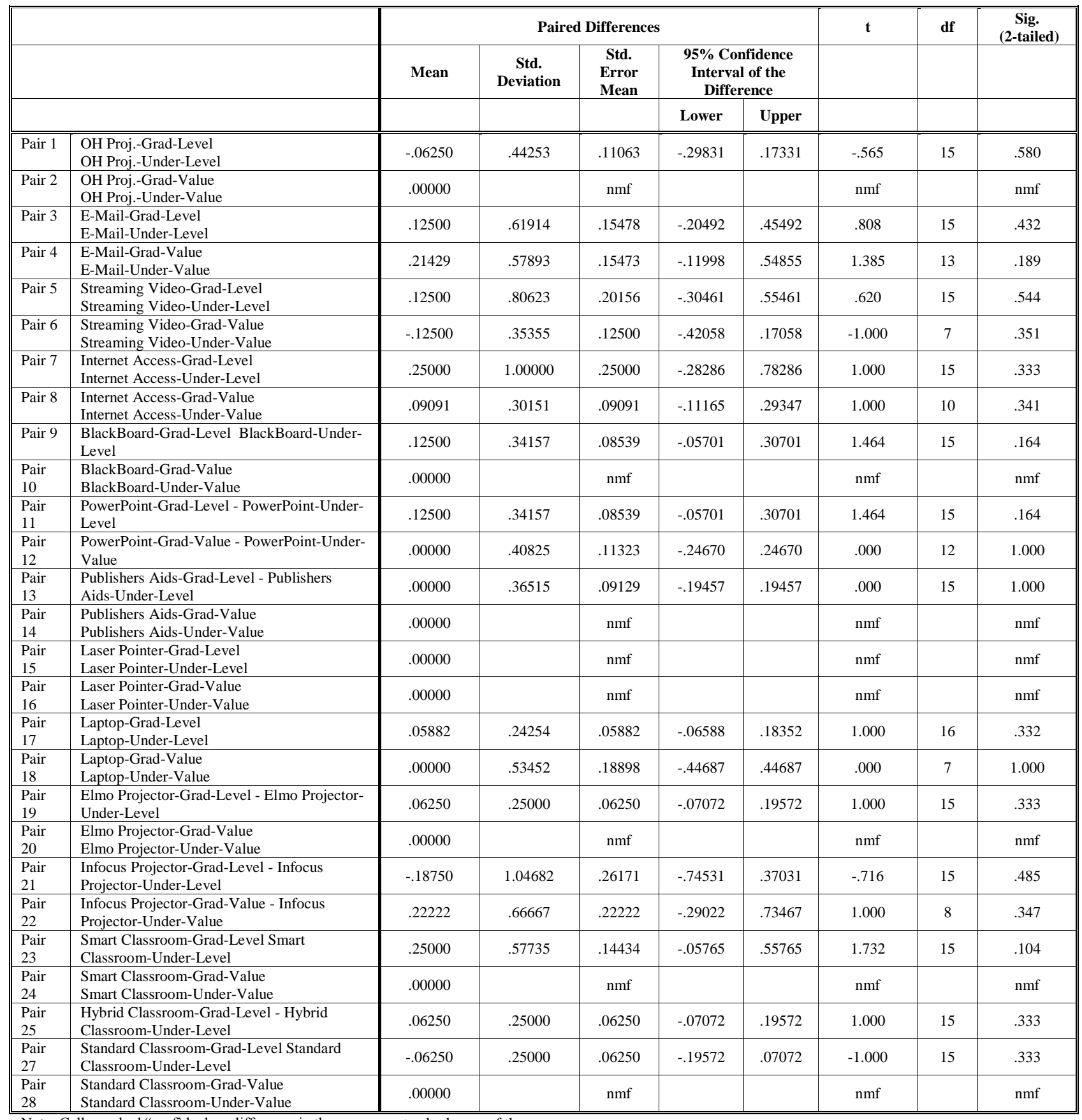

Note: Cells marked "nmf' had no difference in the means or standard error of the mean 
Table 4

Paired Samples Test - Soft Technologies

Graduate and Undergraduate - Level vs. Value of Use

\begin{tabular}{|c|c|c|c|c|c|c|c|c|c|}
\hline & & \multicolumn{5}{|c|}{ Paired Differences } & \multirow[t]{3}{*}{$\mathbf{t}$} & \multirow[t]{3}{*}{ df } & \multirow[t]{3}{*}{$\begin{array}{c}\text { Sig. } \\
\text { (2-tailed) }\end{array}$} \\
\hline & & \multirow[t]{2}{*}{ Mean } & \multirow[t]{2}{*}{$\begin{array}{c}\text { Std. } \\
\text { Deviation }\end{array}$} & \multirow[t]{2}{*}{$\begin{array}{l}\text { Std. Error } \\
\text { Mean }\end{array}$} & \multicolumn{2}{|c|}{$\begin{array}{l}\text { 95\% Confidence } \\
\text { Interval of the } \\
\text { Difference }\end{array}$} & & & \\
\hline & & & & & Lower & Upper & & & \\
\hline $\begin{array}{l}\text { Pair } \\
1 \\
\end{array}$ & $\begin{array}{l}\text { Essay-Grad-Level } \\
\text { Essay-Grad-Value }\end{array}$ & -.50000 & .81650 & .20412 & -.93508 & -.06492 & -2.449 & 15 & .027 \\
\hline $\begin{array}{l}\text { Pair } \\
3\end{array}$ & $\begin{array}{l}\text { Attendance-Grad-Level } \\
\text { Attendance-Grad-Value }\end{array}$ & .33333 & .81650 & .21082 & -.11883 & .78549 & 1.581 & 14 & .136 \\
\hline $\begin{array}{l}\text { Pair } \\
4\end{array}$ & $\begin{array}{l}\text { Attendance-Under-Level } \\
\text { Attendance-Under-Value }\end{array}$ & .21429 & .57893 & .15473 & -.11998 & .54855 & 1.385 & 13 & .189 \\
\hline $\begin{array}{l}\text { Pair } \\
5\end{array}$ & $\begin{array}{l}\text { Research Proj.-Grad-Level } \\
\text { Research Proj.-Grad-Value }\end{array}$ & -.18750 & .54391 & .13598 & -.47733 & .10233 & -1.379 & 15 & .188 \\
\hline $\begin{array}{l}\text { Pair } \\
6\end{array}$ & $\begin{array}{l}\text { Research Proj.-Under-Level } \\
\text { Research Proj.-Under-Value }\end{array}$ & -.35714 & .74495 & .19910 & -.78726 & .07298 & -1.794 & 13 & .096 \\
\hline $\begin{array}{l}\text { Pair } \\
8\end{array}$ & $\begin{array}{l}\text { Guest Lecturers-Under-Level } \\
\text { Guest Lecturers-Under-Value }\end{array}$ & -1.41667 & .66856 & .19300 & -1.84145 & -.99189 & -7.340 & 11 & .000 \\
\hline $\begin{array}{l}\text { Pair } \\
9\end{array}$ & $\begin{array}{l}\text { Teams-Grad-Level } \\
\text { Teams-Grad-Value }\end{array}$ & .00000 & .84515 & .21822 & -.46803 & .46803 & .000 & 14 & 1.000 \\
\hline $\begin{array}{l}\text { Pair } \\
10\end{array}$ & $\begin{array}{l}\text { Teams-Under-Level } \\
\text { Teams-Under-Value }\end{array}$ & -.20000 & .67612 & .17457 & -.57442 & .17442 & -1.146 & 14 & .271 \\
\hline
\end{tabular}

The results in this section indicate a profile of unmet demand for a range of technologies and classroom configurations. While a thorough discussion of the implications of the statistical differences is beyond the scope of this paper, we interpret most of the differences as attributable 1) a process of resource build outs of hybrid classrooms that is underway, 2) an ongoing process of faculty training, and 3) an interaction between hard and soft technologies. The interaction between hard and soft technologies suggests that some of the most highly valued and less used hard technologies such as streaming video and internet access are mostly a function of the current limited number of equipped rooms. As the number of technology capable rooms continues to increase, we suggest that faculty members are convinced of the value proposition and that value and use will come into balance. However, in the short term only a few respondents expressed intent to use most technologies. (Recall this was response five under the level of use questions.) The highest number of those intending to use was three and that intent was to use guest lecturers. A tentative explanation may be that more active policy intervention may be necessary, or that there may be a lag time as faculty members attain a required confidence level with a particular technology. 
Table 5

Paired Samples Test - Hard Technologies Graduate and Undergraduate - Level vs. Value of Use

\begin{tabular}{|c|c|c|c|c|c|c|c|c|c|}
\hline & & \multicolumn{5}{|c|}{ Paired Differences } & \multirow[t]{3}{*}{$\mathbf{t}$} & \multirow[t]{3}{*}{ df } & \multirow[t]{3}{*}{$\begin{array}{c}\text { Sig. } \\
\text { (2-tailed) } \\
\end{array}$} \\
\hline & & \multirow[t]{2}{*}{ Mean } & \multirow[t]{2}{*}{ Std. Deviation } & \multirow[t]{2}{*}{$\begin{array}{l}\text { Std. Error } \\
\text { Mean }\end{array}$} & \multicolumn{2}{|c|}{$\begin{array}{c}\text { 95\% Confidence } \\
\text { Interval of the } \\
\text { Difference }\end{array}$} & & & \\
\hline & & & & & Lower & Upper & & & \\
\hline $\begin{array}{l}\text { Pair } \\
1\end{array}$ & $\begin{array}{l}\text { OH Proj.-Grad-Level } \\
\text { OH Proj.-Grad-Value }\end{array}$ & -.73333 & 1.09978 & .28396 & -1.34237 & -.12429 & -2.582 & 14 & .022 \\
\hline $\begin{array}{l}\text { Pair } \\
2 \\
\end{array}$ & $\begin{array}{l}\text { OH Proj.-Under-Level } \\
\text { OH Proj.-Under-Value }\end{array}$ & -.64286 & 1.00821 & .26945 & -1.22498 & -.06074 & -2.386 & 13 & .033 \\
\hline $\begin{array}{l}\text { Pair } \\
3\end{array}$ & $\begin{array}{l}\text { E-Mail-Grad-Level } \\
\text { E-Mail-Grad-Value }\end{array}$ & -.25000 & .93095 & .23274 & -.74607 & .24607 & -1.074 & 15 & .300 \\
\hline $\begin{array}{l}\text { Pair } \\
4\end{array}$ & $\begin{array}{l}\text { E-Mail-Under-Level } \\
\text { E-Mail-Under-Value }\end{array}$ & -.35714 & .84190 & .22501 & -.84324 & .12895 & -1.587 & 13 & .136 \\
\hline $\begin{array}{l}\text { Pair } \\
5\end{array}$ & $\begin{array}{l}\text { Streaming Video-Grad-Level Streaming } \\
\text { Video-Grad-Value }\end{array}$ & -1.00000 & .94281 & .29814 & -1.67444 & -.32556 & -3.354 & 9 & .008 \\
\hline $\begin{array}{l}\text { Pair } \\
6\end{array}$ & $\begin{array}{l}\text { Streaming Video-Under-Level Streaming } \\
\text { Video-Under-Value }\end{array}$ & -1.12500 & .99103 & .35038 & -1.95352 & -.29648 & -3.211 & 7 & .015 \\
\hline $\begin{array}{l}\text { Pair } \\
8\end{array}$ & $\begin{array}{l}\text { Internet Access-Under-Level Internet } \\
\text { Access-Under-Value }\end{array}$ & -.72727 & .90453 & .27273 & -1.33495 & -.11960 & -2.667 & 10 & .024 \\
\hline $\begin{array}{l}\text { Pair } \\
9\end{array}$ & $\begin{array}{l}\text { BlackBoard-Grad-Level BlackBoard-Grad- } \\
\text { Value }\end{array}$ & -.08333 & .90034 & .25990 & -.65538 & .48871 & -.321 & 11 & .754 \\
\hline $\begin{array}{l}\text { Pair } \\
10\end{array}$ & $\begin{array}{l}\text { BlackBoard-Under-Level BlackBoard- } \\
\text { Under-Value }\end{array}$ & -.11111 & .60093 & .20031 & -.57302 & .35080 & -.555 & 8 & .594 \\
\hline $\begin{array}{l}\text { Pair } \\
11 \\
\end{array}$ & $\begin{array}{l}\text { PowerPoint-Grad-Level PowerPoint-Grad- } \\
\text { Value }\end{array}$ & -.07143 & .82874 & .22149 & -.54993 & .40707 & -.322 & 13 & .752 \\
\hline $\begin{array}{l}\text { Pair } \\
12 \\
\end{array}$ & $\begin{array}{l}\text { PowerPoint-Under-Level PowerPoint- } \\
\text { Under-Value }\end{array}$ & -.23077 & .72501 & .20108 & -.66889 & .20735 & -1.148 & 12 & .273 \\
\hline $\begin{array}{l}\text { Pair } \\
13\end{array}$ & $\begin{array}{l}\text { Publishers Aids-Grad-Level Publishers } \\
\text { Aids-Grad-Value }\end{array}$ & -.37500 & .71880 & .17970 & -.75802 & .00802 & -2.087 & 15 & .054 \\
\hline $\begin{array}{l}\text { Pair } \\
14 \\
\end{array}$ & $\begin{array}{l}\text { Publishers Aids-Under-Level Publishers } \\
\text { Aids-Under-Value }\end{array}$ & -.50000 & .75955 & .20300 & -.93855 & -.06145 & -2.463 & 13 & .029 \\
\hline $\begin{array}{l}\text { Pair } \\
15\end{array}$ & $\begin{array}{l}\text { Laser Pointer-Grad-Level } \\
\text { Laser Pointer-Grad-Value }\end{array}$ & .00000 & .70711 & .31623 & -.87799 & .87799 & .000 & 4 & 1.000 \\
\hline $\begin{array}{l}\text { Pair } \\
16 \\
\end{array}$ & $\begin{array}{l}\text { Laser Pointer-Under-Level } \\
\text { Laser Pointer-Under-Value }\end{array}$ & .00000 & .70711 & .31623 & -.87799 & .87799 & .000 & 4 & 1.000 \\
\hline $\begin{array}{l}\text { Pair } \\
18\end{array}$ & $\begin{array}{l}\text { Laptop-Under-Level } \\
\text { Laptop-Under-Value }\end{array}$ & -1.00000 & .92582 & .32733 & -1.77400 & -.22600 & -3.055 & 7 & .018 \\
\hline $\begin{array}{l}\text { Pair } \\
19\end{array}$ & $\begin{array}{l}\text { Elmo Projector-Grad-Level } \\
\text { Elmo Projector-Grad-Value }\end{array}$ & -.55556 & .72648 & .24216 & -1.11398 & .00287 & -2.294 & 8 & .051 \\
\hline $\begin{array}{l}\text { Pair } \\
20 \\
\end{array}$ & $\begin{array}{l}\text { Elmo Projector-Under-Level } \\
\text { Elmo Projector-Under-Value }\end{array}$ & -.85714 & .89974 & .34007 & -1.68926 & -.02503 & -2.521 & 6 & .045 \\
\hline $\begin{array}{l}\text { Pair } \\
21\end{array}$ & $\begin{array}{l}\text { Infocus Projector-Grad-Level Infocus } \\
\text { Projector-Grad-Value }\end{array}$ & -.45455 & 68755 & .20730 & -.91645 & .00736 & -2.193 & 10 & .053 \\
\hline $\begin{array}{l}\text { Pair } \\
22 \\
\end{array}$ & $\begin{array}{l}\text { Infocus Projector-Under-Level Infocus } \\
\text { Projector-Under-Value }\end{array}$ & -.33333 & .70711 & .23570 & -.87686 & .21020 & -1.414 & 8 & .195 \\
\hline
\end{tabular}

Figures in Bold = significant at .05 
Table 6

Paired Samples Test - Classroom Type Graduate and Undergraduate - Level vs. Value of Use

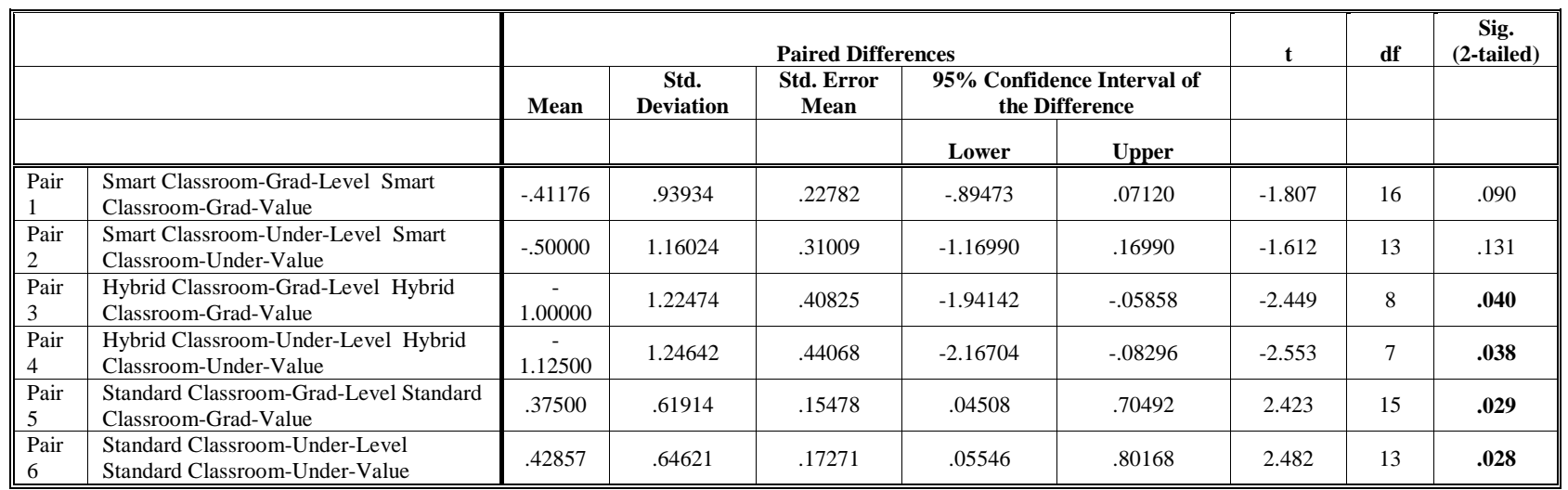

Figures in Bold = significant at .05

Research Question 5: What are the effects of the factors teaching experience, teaching field, and tenure status on the mean responses for each significant difference?

We tested the role of teaching experience, teaching area, and tenure status by running a series of ANOVAs in a fixed effects model for all items identified as significant in the paired t tests. Figure 6 shows the result for an ANOVA with the soft technology item Essay at the Graduate level for perceived Value of Use. The factors were insignificant. All such ANOVAs were insignificant at the .05 level. The instructional environment within which we gathered the data, although functionally broken into departments, is physically integrated with various department members interspersed, and is characterized by a relatively high level of interaction among faculty members without regard to departmental affiliation. All faculty members face similar opportunities and constraints regarding the various technologies and class settings. Finally, for many of the items, there may be no a priori reason to expect significant differences. Even in areas such as Accounting, there has been a consistent thrust to incorporate technology, teams, and writing into the learning experience. We tentatively conclude that a secular trend towards the desire to use similar methods and tools coupled with a small and integrated faculty cadre suggests that both valued technologies and valued teaching settings should be roughly similar across departments.

With respect to tenure status, the series of ANOVAs yielded no significant findings. Hard technology adoption and recognition of the values of certain soft technologies such as the use of teams affected the faculty broadly. With respect to teaching experience, none of the ANOVAs yielded a significant finding. Teaching experience was strongly correlated with tenure.

We conclude with respect to research question five, that under the conditions of a relatively small, physically integrated, and interactive faculty, the factors of department, teaching experience, and tenure were not significant in explaining variable levels in either variable in pairings found significant by the $t$ tests. 
Table 7

ANOVA - Tests of Between-Subjects Effects

Dependent Variable: Essay-Grad-Value

\begin{tabular}{|c|c|c|c|c|c|}
\hline Source & $\begin{array}{c}\text { Type III Sum of } \\
\text { Squares } \\
\end{array}$ & df & Mean Square & $\mathbf{F}$ & Sig. \\
\hline Corrected Model & 2.771(a) & 11 & .252 & .318 & .941 \\
\hline Intercept & 111.005 & 1 & 111.005 & 140.217 & .000 \\
\hline TENURE & .010 & 1 & .010 & .012 & .917 \\
\hline TEXP & .850 & 2 & .425 & .537 & .622 \\
\hline TFIELD & 1.050 & 4 & .262 & .331 & .845 \\
\hline TENURE $*$ TEXP & .000 & 0 & . & . &. \\
\hline TENURE * TFIELD & .480 & 1 & .480 & .607 & .480 \\
\hline TEXP $*$ TFIELD & .350 & 2 & .175 & .221 & .811 \\
\hline TENURE $*$ TEXP $*$ TFIELD & .000 & 0 & . & . & . \\
\hline Error & 3.167 & 4 & .792 & & \\
\hline Total & 195.000 & 16 & & & \\
\hline Corrected Total & 5.938 & 15 & & & \\
\hline
\end{tabular}

(a) R Squared $=.467$ (Adjusted R Squared $=-1.000$ )

Note: ANOVA were run for each pair member in each significant t-test. All of the three factors (tenure, experience, or department) were not significant at .05 in all ANOVA analyses.

\section{Discussion, Limitations, and Future Research}

We believe that the primary intent of the research has been achieved, mainly, to develop an accurate profile of what this particular faculty group is actually using by way of selected teaching methods and technologies. In addition we have solid clues as to how various factors are valued by the faculty on both the undergraduate and graduate (MBA and MS) level. While this information is delimited by the small size of the sample $(\mathrm{n}=18)$, nonetheless many statistically significant results were achieved that provide valuable insight into the actual classroom practices of the faculty. Clearly, it is impossible to generalize from this research; however, researchers might wish to take note of some of the findings for future research.

The third phase of this research will be to administer the same survey instrument to the adjunct faculty in the Adelphi University School of Business which numbers about thirty faculty members. The goal will be to first, develop the same profile of teaching methods and technologies as was done for the full time faculty. Secondly, a comparison of the results for both groups will be examined. Thus, having empirical data for both groups will permit a more robust understanding of how the faculty as a whole is using the "hard" and "soft" technologies and how these methods are valued and actually used. Should significant differences exist between the full and part time faculty it will be extremely important to understand why those difference exist. There is an implicit assumption that there are no fundamental differences or invariance between the two groups. The research goal is to find out. The ultimate goal is to assist in the continuous improvement process within the Adelphi University School of Business.

With so much research being conducted on the influence of technology in the learning process it is hoped that this research will provide a basis to examine the levels and value of use of various teaching methods and technologies on a larger scale for faculty. The research conducted by EDUCAUSE (Morgan 2003) on faculty use of one item, course management software, was a valuable contribution but focused on only one element of the modern teaching process.

As a consequence of this study researchers in the future will have clues to examine in new research on faculty teaching methods and practices. It must be noted, however, that given the small size of the sample no generalization of the results can be made. There is significant local value in using the results to gain a profile of this particular faculty group with respect to continuous improvement initiatives for both the use of emerging technologies and teaching methods.

\section{ACKNOWLEDGEMENTS}

The authors would like to express their appreciation to Dean Anthony F. Libertella for encouraging this research in the first place and to Dr. Allan Ashley, Chair of the Marketing, Management, and Decision Sciences 
Department for his support and counsel during the research. Appreciation is also extended to Ms. Amber Haines, Graduate Assistant, who provided invaluable technical support.

\section{REFERENCES}

1. Adelphi University Faculty Center for Professional Excellence, http://jcpe.adelphi.edu

2. Alexander, Shirley, "Teaching and Learning on the World Wide Web" Institute for Interactive Multimedia, University of Technology (date), http://ausweb.scu.edu.au/aw95/educationz/alexander/index.html.

3. Arabasz, Paul and Baker, Mary Beth, "Evolving Campus Support Models for E-learning Courses, Respondent Summary, "EDUCAUSE Center for Applied Research, Boulder, Colorado, March 2003.

4. Blackboard Course Management Software, "www.blackboard.com/support.

5. Blackboard, http://www.blackboard.com/about/index.htm.

6. Bradley, Robert E. and Quigley, Mark, "Transforming the Faculty: A Case Study at a Comprehensive University, Faculty Development Center, Adelphi University, 2001.

7. Caruso, Judith Borreson, Educause Center for Applied Research "ECAR, Study of Students and Information Technology, Key Findings, 2004: Convenience, Connection and Control, Boulder, Colorado.

8. Dalhousie University's Instructional Development and Technology Sites Worldwide, Office of Instructional Development and Technology: http://www.dal.ca/noidt/ids.html.

9. Gokhale, Anuradha A., "Collaborative Learning Enhances Critical Thinking," http://scholar.lib.vt.edu/ ejournals/jte/ jte-v>n//gokhale.jte-v7n1.html.

10. Hall, Mark and Elliot, Kevin M., "Diffusion of Technology into the teaching process: Strategies to encourage faculty members to embrace the lap top environment," Journal of Education for Business. Washington July/August 2003. Vol.78.

11. Ma, Yulong and Runyon, L.R., "Academic Synergy in the Age of Technology - A New Instructional Paradigm," Journal of Education for Business. Washington - July/August 2004. Vol. 79, ProQuest document ID 692351181.

12. Morgan, Glenda. "Faculty Use of Course Management Systems, Key Findings, " EDUCAUSE Center for Applied Research (ECAR), Boulder, Co., May 2003.

13. Office of Information Technology, University of Maryland, hhtp://oit.umd.edu/units/as.

14. Office of Instructional Consultation, University of California at Santa Barbara, http://www.id.ucsb.edu/ic/resources/collab-1/difference.html.

15. Payette, Dennis L., "Enhanced Multi-Faceted Teaching Methods," Journal of College Teaching and Learning, Vol. 1, Number 6, June 2004.

16. Rogers, E.M., Diffusion of Innovation ( $3^{\text {rd }}$ ed.) New York: The Free Press 1983.

17. Ullman, Craig and Rabinowitz, Mitchell "Course Management Systems and the Reinvention of Instruction", T.H.E. Journal Web Exclusive, October 2004, http://thejournal.com/magazine/vault/A5070.cjm.

18. University of Wisconsin, Course Management System Survey, EDUCAUSE Center for Applied Research, Vol. 2, 2003.

19. Wark, Elizabeth J., "Technology as a Tool, Not a Teacher Replacement" Letter to the Teaching Professor, Magna Publications, October 2004.

20. Young, Jeffrey R., "Students Say Technology has Little Impact on Teaching," Chronicle of Higher Education; 8/13/2004, Vol. 50 Issue 49, PA 28, 1/3p. 


\section{NOTES}

